Acta Theriologica 43 (2): 137-161, 1998.

PL ISSN $0001-7051$

\title{
Spatial behaviour and population dynamics of woodland rodents
}

\author{
Maria MAZURKIEWICZ and Ewa RAJSKA-JURGIEL
}

\begin{abstract}
Mazurkiewicz M. and Rajska-Jurgiel E. 1998. Spatial behaviour and population dynamics of woodland rodents. Acta Theriologica 43: 137-161.

Population dynamics and spatial behaviour of the vole Clethrionomys glareolus (Schreber, 1780) and the yellow-necked mouse Apodemus flavicollis (Melchior, 1834) were studied for 7 years in woodland of Kampinos National Park, Poland. Mice were more mobile and less site-tenacious than voles. Annual peaks ranged from 9 to 104 voles and from 4 to 62 mice per ha. The highest densities of both species were preceded by winter breeding. The greatest movement range and the longest distance moved were observed in the years of low density, whereas in the high density year both species were least mobile and most site-tenacious. Intensive movements in the low density years led to early maturation, high turnover rates, and probably increased mortality. Low mobility and high site tenacity in the high density year enhanced population growth and suppressed maturation. Increasing density and cessation of breeding accounted for declining juvenile recruitment. Differences in movement patterns between years of low and high density were coupled with differences in the autumn age structure and winter mortality of both species.
\end{abstract}

Department of Vertebrate Ecology, Institute of Ecology, Polish Academy of Science, Dziekanów Leśny, 05-092 Łomianki, Poland

Key words: Clethrionomys glareolus, Apodemus flavicollis, spatial behaviour, population dynamics

\section{Introduction}

Animal densities are usually higher in resource rich habitats (Pimm and Rozenzweig 1981). A local increase in the available food supply often causes an influx of immigrants (Andrzejewski 1963, 1975, Hansson 1971, Flowerdew 1976, 1985, Boutin 1990, Brandt 1992, Löfgren et al. 1996). As a result of heavy seed crops or supplying additional food, rodent densities are high in the following years (Zejda 1962, Bujalska 1975, Andrzejewski and Mazurkiewicz 1976, Jensen 1982a, Mazurkiewicz and Rajska-Jurgiel 1987, Pucek et al. 1993). Spatial distribution of many species depends thus on the distribution of necessary resources, although this need not be only food but can be the abundance of shelters (Mazurkiewicz 1984, 1994). Long-term population dynamics of various rodent species largely reflects the dynamics of their resources, at least in temperate environment (Flowerdew 1985, Pucek et al. 1993, Jędrzejewski and Jędrzejewska 1996, Wolff 1996). 
In contemporary fragmented landscapes, the abundance of animals primarily depends on the availability of suitable habitats. However, to predict the chance of species survival in changing landscapes we must also know their spatial behaviour that will determine the minimum patch size of these habitats and their acceptable level of isolation. Especially disturbing today is forest fragmentation. In isolated, small woodlots, densities of the yellow-necked mouse Apodemus flavicollis (Melchior, 1834) were always higher than densities of the bank vole Clethrionomys glareolus (Schreber, 1780) (Rajska-Jurgiel and Mazurkiewicz 1988, Rajska-Jurgiel 1992), although in extensive forests bank voles are typically several times more abundant (Mazurkiewicz and Rajska-Jurgiel 1978, 1987). The effect of isolation and habitat fragmentation on vole abundance was also found by Gliwicz (1989) and van Apeldoorn et al. (1992). More rapid colonization of woodlots by mice than by voles was observed by Kozakiewicz and Jurasińska (1989). The abundance of voles on woodland edges is lower and that of mice is similar or higher than in forest interior (Mazurkiewicz and Rajska-Jurgiel 1987).

The biology of the bank vole and the yellow-necked mouse is fairly well known (Golley et al. 1975, Petrusewicz 1983, Flowerdew et al. 1985). Their optimal habitats in central Europe are fertile deciduous and mixed-deciduous forests (Pucek 1983, Flowerdew et al. 1985). The two species differ in food habits and anti-predator adaptation. Mice are granivorous and the seeds of forest trees are their predominant food resource (Drożdż 1966, Zemanek 1972, Jensen 1982a). Bank voles are folivorous-granivorous (Holišova 1971, Gębczyńska 1976, 1983). Both species supplement their diet with invertebrates. However, the potential food spectrum of voles is much wider than that of mice. List of food items taken by voles covers most of those eaten by mice, although many food species eaten by voles are not touched by mice (Hansson 1985). Thus, the two species depend on resources of different availability. Spatial and temporal distribution of food resources is also more variable for mice than for voles. Mice with their large eyes and ears, nocturnal activity and powerful escape leaps are better equipped than voles to detect and avoid predation (King 1985, Ylönen et al. 1992). Active during daytime and slowly moving voles, with little possibility to escape predation, are more dependent on cover than mice. Mice are habitat specialist restricted mainly to mature woodland (Montgomery 1979, 1980, Gurnell 1985, but see Adamczewska-Andrzejewska et al. 1981). Voles are habitat generalist, inhabiting practically all types of forests (Pucek 1983), with a preference for dense ground cover (Jensen 1982b, Wiger 1982, Mazurkiewicz 1984, 1986, 1991, 1994, Chętnicki and Mazurkiewicz 1994).

Spatial behaviour may translate to population dynamics (Wiens et al. 1993). Despite much research there remain large gaps in our knowledge of movement patterns of the bank voles and especially of the yellow-necked mouse. The bank vole is considered to be a species which is site-tenacious (Nikitina 1970, Mazurkiewicz 1971, Löfgren 1995) and less mobile than the yellow-necked mouse (Bergstedt 1966, Mazurkiewicz and Rajska-Jurgiel 1987, but see Andrzejewski and Babińska-Werka 1986, Kozakiewicz and Szacki 1995, Liro and Szacki 1995). 
In forests of central Europe, population dynamics of both the bank vole and the yellow-necked mouse are characterized by regular annual cycles and irregular long-term fluctuations (Alibhai and Gipps 1985, Flowerdew 1985). High numbers following winter breeding occur in both species in the years preceded by a heavy mast crop (Zejda 1962, Smyth 1966, Bäumler 1981, Jensen 1982a, Mazurkiewicz and Rajska-Jurgiel 1978, 1987, Pucek et al. 1993). The age structure of the spring population at high abundance differs from that at moderate or low abundance and breeding is terminated already in mid-July (Adamczewska 1961, Jensen 1982a).

Differential food abundance from year to year may influencenot only the density but also the spatial behaviour of rodents. The choice between staying in the natal site or dispersal can significantly affect the fates of individuals and be of great importance to regulation of the population density. There is a large literature about processes and features besides resources that may affect population dynamics. Here we are concerned with resource availability and movement patterns of temperate forest rodents. The objectives of this study were: (1) to compare spatial behaviour of two rodent species, the bank vole and yellow-necked mouse, in their natural habitats in continuous forests, and (2) to analyse the relationship between spatial behaviour of these rodents and their population dynamics and structure. We predict that: (1) species living on more limited food resources should hold larger home ranges, (2) home range size of such species should be more affected by changes in food supply, (3) maturation rates of species restricted in maturation by vacant space supply rather than by food availability should be more affected by density, (4) if competition for food resources is the main reason for dispersal then species depending on scarcer resource should be more prone to disperse, (5) if competition for place to breed is the main reason for dispersal then dispersal rates of species with lower maturation rates should be more affected.

\section{Study area, material, and methods}

The study area was located in the Kampinos Forest which is a large forest complex $\left(225 \mathrm{~km}^{2}\right)$ near Warsaw $\left(52^{\circ} 20^{\prime} \mathrm{N}, 20^{\circ} 51^{\prime} \mathrm{E}\right)$. In $1982-1985$ the study was carried out on a 3.5 -ha plot with 8 lines of 16 live-traps $15 \mathrm{~m}$ apart. In 1984-1985, the plot was extended to 12 ha by adding 8 lines of 16 live-traps $15 \mathrm{~m}$ apart that paralleled longer sides of the grid. Distances between lines varied from 15 to $90 \mathrm{~m}$. The reason was to estimate whether the rodents were prevented from expressing their normal ranges by the uniform distribution of closely spaced trap. In 1987-1989, the study was conducted on a 6-ha plot (15 lines of 16 traps at $15 \mathrm{~m}$ intervals) situated about $1200 \mathrm{~m}$ from the earlier plot. The plots were located in a mosaic of mixed coniferous forest and deciduous forest.

Each 7ear, four trapping sessions (each lasting 7 days) were carried out at 6 -week intervals. The capture-recapture method (CMR) was used. All rodents were individually marked. Traps were checked twice daily. At each capture we noted the rodent species, its number, trap location, sex and reproductve condition (closed or perforated vagina in females, testes abdominal or scrotal in males), body weight and age (based on the body size and pelage color; see Mazurkiewicz and Rajska-Jurgiel 1987, Rajska-Jurgiel 1992). 
Densities per ha were estimated by common census method for each trapping session on plots covered with trap grids. The abundance of rodents was also estimated as numbers of rodents trapped per 100 trap-days in each trapping sessions on each of the plots. The mean number of mature and immature males and females per trapping session in the period May-August was calculated for each year. Percentages of the trap stations occupied, number of rodents per trap station and total captures were calculated for each trapping session.

Home range sizes and geometric centres of activity of rodents were estimated in particular trapping sessions on every plot. As an index of home range size we used the maximum distance in metres between captures of an individual (Observed Range Length $=\mathrm{ORL}$ ), with the smallest distance between trap points $(15 \mathrm{~m})$ added. This analysis was done only for individuals caught at least 4 times as (1) the distance between captures did not show a significant increase with successive captures, and (2) distributions of the number of captures of these individuals did not differ significantly among plots and between high and low population density. For all individuals present in 2 or more trapping sessions we estimated the total observed range of movements (TRL) as the maximum distance between their captures over the time of their presence on the plot. To analyse the effect of the length of observation period on the estimate of movement range of rodents, 3 groups of individuals were distinguished with respect to the time on the plot (1,2, and 3 or more trapping sessions).

For individuals present in at least 2 trapping sessions, we analysed the home range shifts between two consecutive trapping sessions. The shift was estimated as (1) the distance between the last capture in the preceding trapping session and the first capture in the next session (LFD), and (2) the distance between geometric centres of home ranges in two successive trapping sessions (CCD). Winter shifts of home ranges (between the autumn and spring trapping sessions) are excluded from this analysis. For individuals present in at least 3 trapping sessions, we calculated the total distance of their shift between the first and the third trapping session. For individuals present in at least two trapping sessions, we compared their CCD with their ORL in the preceding trapping session. Individuals that shifted the centres of their home ranges to a distance shorter than ORL were designated as remaining within the boundaries of their earlier home range. Individuals that shifted the centres of their home ranges to a distance longer than ORL were designated as abandoning their home ranges.

Residency of rodents was estimated as the percentage of individuals present on the plot for a given number of trapping sessions (1, 2, 3, or more). Mean loss rates were estimated as percentage of rodents disappearing between particular trapping sessions. To distinguish between emigration and mortality, we calculated emigration rates of recruits assuming their $30 \%$ monthly mortality (French et al. 1975). To compare the relative age structure of the population, the distributions of body mass and the distributions of numbers of individuals marked in different seasons of the year were used.

The measures of movements were compared between years as well as between species by Kolmogorov-Smirnov two-sample test $(K-S)$. We felt that comparisons of percentage distributions rather than averages would be more informative and logical, when distributions were mostly skew.

\section{Results}

\section{Population density and structure}

The data set comprised 10259 captures of 1579 bank voles, and 3900 captures of 1314 yellow-necked mice. Additionally, 120 striped field mice Apodemus agrarius and a few root voles Microtus oeconomus were also captured. The most of striped field mice were trapped only once. None of them were present for longer than one trapping session in August or October. Being highly mobile, striped field mice invade woodlands after harvesting in the crop fields (Mazurkiewicz and 
Rajska-Jurgiel 1987). Twenty five percent of yellow-necked mice and $18 \%$ of bank voles were trapped only once.

In particular trapping sessions, the abundance of rodents (numbers of individuals trapped per 100 trap-days) varied from 0.25 to 30.5 for voles and from 0.1 to 19.5 for mice. Per ha densities were positively correlated with the abundance of rodents on the grids (voles: $r=0.995, \mathrm{df}=26, p<0.001$; mice: $r=0.997, \mathrm{df}=26$, $p<0.001$ ). The abundance of rodents trapped in particular trapping sessions on 8 trap-lines paralleling the 3.5 -ha grid in $1984-1985$ was positively correlated with the abundance on the grid (voles: $r=0.955, \mathrm{df}=7, p<0.001$; mice: $r=0.934$, $\mathrm{df}=7, p<0.001$ ). The abundance of rodents on trap-lines was slightly higher than that on the grid and increasing with the distance to nearest line (E. Rajska-Jurgiel and M. Mazurkiewicz, in prep.). Mean numbers of rodents trapped on the grid and mean numbers of rodents trapped on the lines per trapping session $(21.6 \pm$ 16 and $25.6 \pm 21$ for voles; $9 \pm 5.4$ and $10 \pm 7$ for mice) did not differ significantly (One-way ANOVA; voles: $F=0.182, \mathrm{df}=15, p=0.681$; mice: $F=0.109$, df $=15$, $p=0.750$ ). A crude index was used as the goal was to make comparison, not to measure density. However, population densities over the 12-ha plot with uneven distribution of trap stations were similar to those on the 3.5 ha plot.

Over the seven years of the study, early-spring population densities varied from 1 to $30 \mathrm{inds} / \mathrm{ha}$ for voles and from 1 to 25/ha for mice (Fig. 1). Except in 1983 and 1989 , only single juveniles were captured. In 1989, unusually early spring and accelerated growth of the vegetation resulted in an early beginning of breeding (Rajska-Jurgiel 1992). Some juveniles up to $17 \mathrm{~g}$ in voles and up to $24 \mathrm{~g}$ in mice were captured. However, high spring densities did not result in high annual peaks (Fig. 1). In 1983, heavy seed crop of deciduous trees resulted in winter breeding (Pucek et al. 1993). Spring populations were five times those in previous autumn (Fig. 1). The distributions of body mass of unmarked rodents differed between 1983 and 1989 ( $K-S$ test; voles: $D=0.405, p<0.001$; mice: $D=0.628, p<0.001$ ). In $198360 \%$ of the unmarked voles were already fully-grown adults with body mass more than $20 \mathrm{~g}$. Also $50 \%$ of the unmarked mice were adults with body mass more than $27 \mathrm{~g}$.

Annual peak densities varied from 9 to 104/ha for voles and from 4 to $62 /$ ha for mice (Fig. 1). The highest densities of both species were preceded by winter breeding. In the remaining years, neither annual peaks depended on the spring density (voles: $r=0.460, \mathrm{df}=5, p=0.358$; mice: $r=0.510$, $\mathrm{df}=5, p=198$ ), nor October density did (voles: $r=-0.249, \mathrm{df}=5, p=0.533$; mice: $r=0.501, \mathrm{df}=5$, $p=203$ ). In 1983, peak population density was 10 times those in 1982,1984 , and 1985 for voles and 6 times those in 1982, 1984, 1985, and 1988 for mice. The remaining study years, that is $1987-1989$ for voles and 1987 and 1989 for mice, were the years of moderate density (at the end of August, the density of each species was 2-3 times those in the low density years (Fig. 1). Winter mortality varied from $40 \%$ in 1982 to $95 \%$ in 1983 in voles and from $33 \%$ in 1988 to $93 \%$ in 


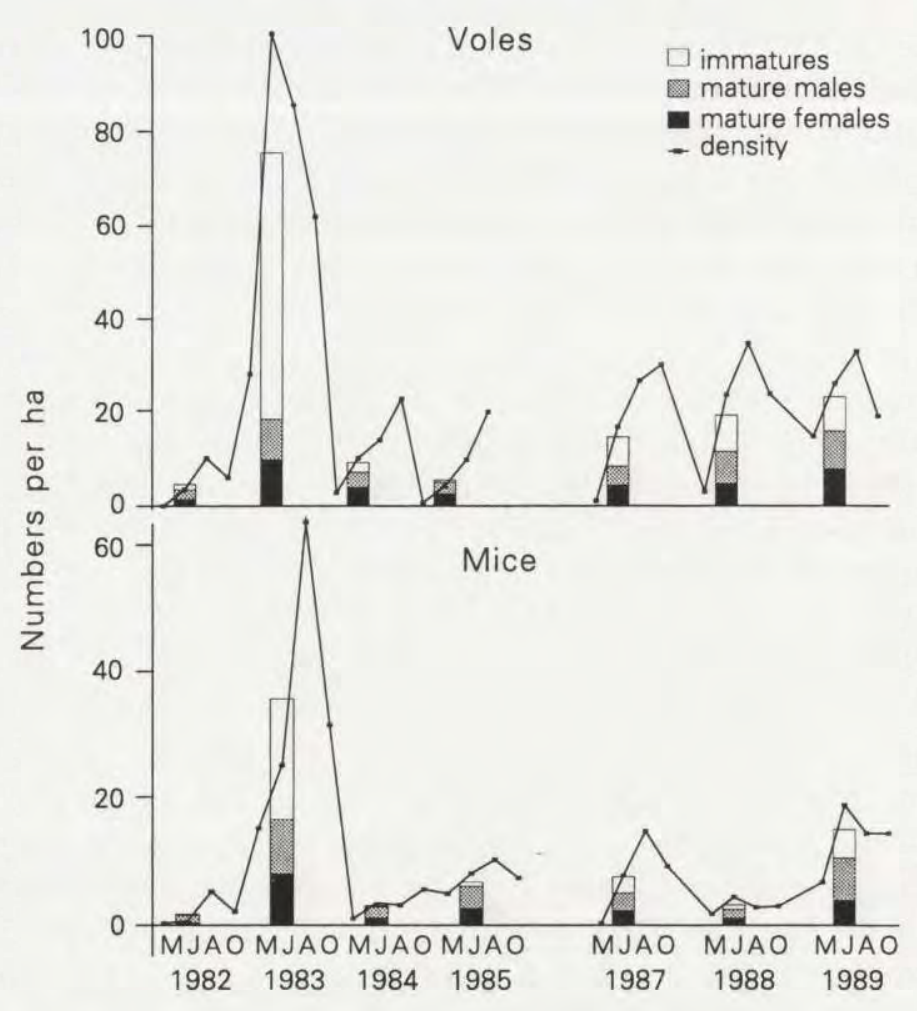

Fig, 1. Changes in population density and breeding structure (mean number of mature males and females and immature individuals per trapping session in the period May-August) for voles and mice.

1983 in mice. Thus, the lowest winter mortality for both species was coupled with low, and the highest with high autumn numbers.

Year-to-year differences were found in the maturation rate of year born young. The proportions of young maturing by autumn in the years of low, moderate, and high density were 85,55 , and $20 \%$, respectively, for voles and 90,70 , and $50 \%$, respectively, for mice. Thus, differences in population density were coupled with differences in the proportions of breeders in both species. In the low density years the populations consisted mainly of mature individuals, whereas in the high density year immature individuals prevailed (Fig. 1). Although the proportions of breeders in the populations of both species were lowest in the year of high density, their numbers were the highest (Fig. 1).

Percentages of the trap stations occupied by rodents as well as mean numbers of rodents per trap station varied in particular trapping sessions with changes in density (Fig. 2). The total space occupied in successive years of the study was 88 , $100,98,94,98,95$, and $95 \%$ trap stations for voles and $32,100,50,83,90,77$, and $95 \%$ trap stations for mice. 


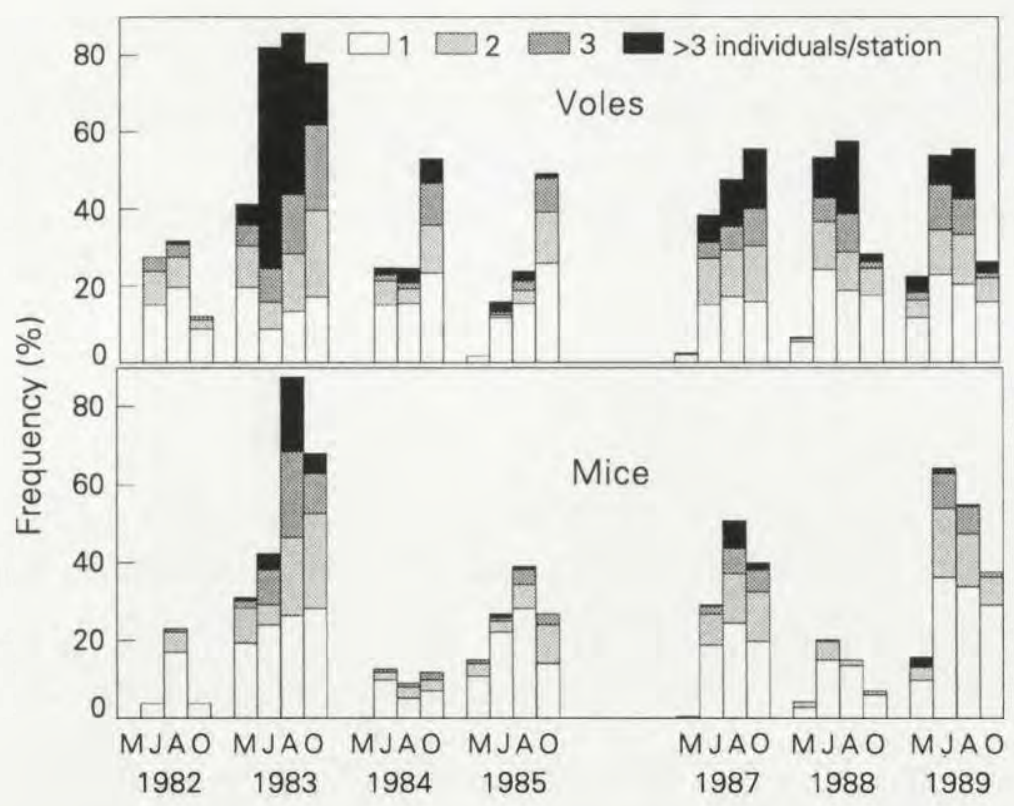

Fig. 2. Percentages of occupied trap stations in successive trapping sessions and their frequency distributions in relation to the number of individuals trapped.

\section{Movement range}

The maximum Observed Range Length (ORL) was over $400 \mathrm{~m}$ in both species. However, most individuals of the two species had ORL's below $100 \mathrm{~m}$ at high and low population densities on all the study plots. At the same time, ORL's smaller than $30 \mathrm{~m}$ were not observed, except in 1983. In both species, the ORL varied greatly during the study. This variation was a result of year-to-year differences in ORL, although in all the study years ORL's were smaller in late autumn than in the breeding season (two-way ANOVA, voles; year-to-year effect: $F=47.8$, $\mathrm{df}=1685, p<0.001$; seasonal effect: $F=8.0, p<0.01$; mice, year-to-year effect: $F=34.5$, df $=742, p<0.001$; seasonal effect: $F=3.2, p<0.05)$. Mean ORL in different trapping sessions varied from 35 to $100 \mathrm{~m}$ in voles and from 50 to 140 $\mathrm{m}$ in mice (Fig. 3). The mean ORL was correlated with the annual peak density (whole data set, voles: $R^{2}=64 \%, \mathrm{df}=25, p<0.001$; mice: $R^{2}=65 \%$, df $=25$, $p<0.001$; May-August trapping sessions, voles: $R^{2}=78 \%$, $\mathrm{df}=19, p<0.001$; mice: $R^{2}=83 \%, \mathrm{df}=19, p<0.001$ ).

Total captures in a trapping session ranged from 3 to $48 \%$ of the possible capture opportunities (Fig. 3). To find out whether the estimate of ORL was influenced by the level of trap saturation, we compared frequency distributions of ORL between trapping sessions with different trap saturation in the high density year (1983) as well as between trapping sessions with a similar trap saturation 


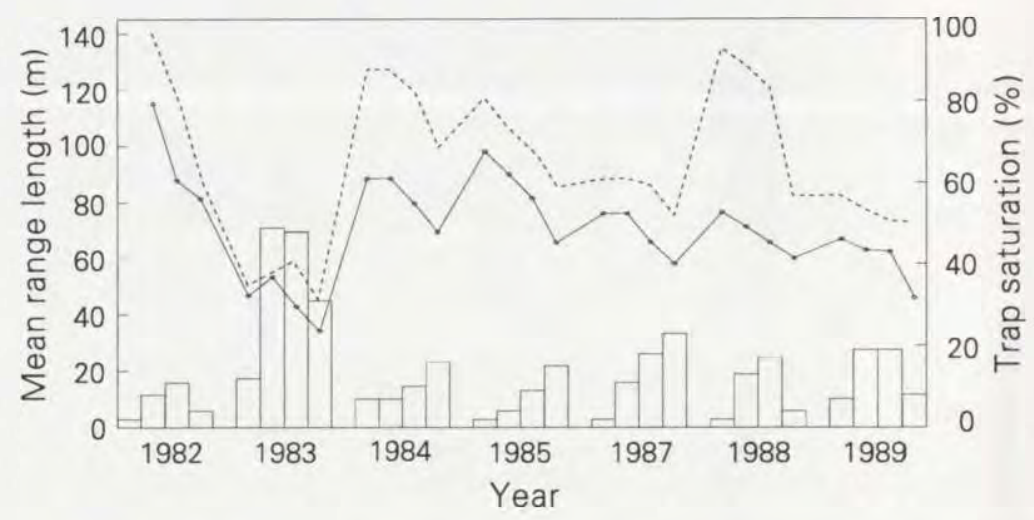

Fig. 3. Percentages of trap saturation (bars) and average home range lengths of voles (solid line) and mice (broken line) in succesive trapping series.

in different years (May 1983, July 1987, July 1988, October 1984 and October 1985; see Fig. 3). No significant differences were found for any species between May and July 1983. ( $K$-S test; voles: $D=0.147, p=0.55$; mice: $D=0.246, p=$ 0.35). Independent of the level of trap saturation both species supported similar home ranges. Significant differences were found between August and October, ORLs in October being shifted towards smaller sizes ( $K$ - $S$ test; voles: $D=0.294$, $p<0.001$; mice: $D=0.298, p<0.01$ ), in spite of better capture opportunities. ORL's of both species were significantly smaller in May 1983 than in July 1987 ( $K$-S test; voles: $D=0.375, p<0.001$; mice: $D=0.502, p<0.001$ ), July 1988 (voles: $D=0.328, p<0.001$; mice: $D=0.557, p<0.001$ ), October 1984 (voles: $D=0.273$, $p<0.001$; mice: $D=0.536, p<0.01$ ), and October 1985 (voles: $D=0.271, p<0.01$; mice: $D=0.333, p<0.05$ ). Independent of the similar level of trap saturation both species hold smaller home ranges in 1983 than in other years. In a step wise multiple regression of the mean range length on: (1) the annual peak density, (2) density in a trapping session in question, (3) percentage of trap saturation, and (4) an index of the season (May, June, August and October) only annual peak density and the index of the season entered the model (voles: $R^{2}=79 \%$, df $=25$, $p<0.001$; mice: $R^{2}=84 \%, \mathrm{df}=25, p<0.001$ ).

In different years, the mean ORL varied from 45 to $95 \mathrm{~m}$ for voles and from 55 to $125 \mathrm{~m}$ for mice. As no significant differences were found on the 6 -ha and 12-ha plots, the material from each of these plots was combined for all the study years, whereas the material from the 3.5-ha plot was analysed separately for the year of high density (1983) and for the low density years (1982, 1984, 1985).

To find out whether the estimate of ORL was influenced by the plot size, we compared frequency distributions of ORL between 3.5-ha and 12-ha plots. Although the maximum ORL was higher on the 12-ha plot, no significant effect of plot size were found for either species (Table 1$),(K-S$ test; voles: $D=0.135$, 
Table 1. Percentage distributions of observed home range length (ORL) for voles and mice on different plots at different population densities. Differences between distribution at low and high density were significant ( $K-S$ test; voles: $D=0.387, p<0.001$; mice: $D=0.251, p<0.05$ ). $n$ - sample sizes.

\begin{tabular}{|c|c|c|c|c|c|c|c|c|}
\hline \multirow{2}{*}{ Species } & \multirow{2}{*}{ Plot (ha) } & \multirow{2}{*}{ Density } & \multirow{2}{*}{$n$} & \multicolumn{5}{|c|}{ Home range length (ORL) } \\
\hline & & & & 50 & 100 & 150 & 200 & $>200 \mathrm{~m}$ \\
\hline \multirow[t]{4}{*}{ Voles } & 3.5 & High & 464 & 74.6 & 18.0 & 4.7 & 2.3 & 0.4 \\
\hline & & Low & 368 & 37.2 & 40.2 & 9.4 & 8.7 & 4.5 \\
\hline & 6 & Moderate & 854 & 51.6 & 32.5 & 9.9 & 3.8 & 2.3 \\
\hline & 12 & Low & 428 & 42.4 & 33.3 & 9.5 & 7.1 & 7.6 \\
\hline \multirow[t]{4}{*}{ Mice } & 3.5 & High & 199 & 60.0 & 26.3 & 10.5 & 2.6 & 0.5 \\
\hline & & Low & 181 & 14.9 & 47.5 & 22.6 & 9.4 & 5.5 \\
\hline & 6 & Moderate & 363 & 28.3 & 53.3 & 12.5 & 3.3 & 2.5 \\
\hline & 12 & Low & 256 & 14.5 & 42.2 & 20.5 & 12.0 & 10.8 \\
\hline
\end{tabular}

$p=0.093$; mice: $D=0.153, p=0.338$ ). Only $14 \%$ of voles and $16 \%$ of mice among those trapped on the 3.5 ha plot were also trapped outside that plot. Most of them were mature adult males (E. Rajska-Jurgiel and M. Mazurkiewicz, in prep.).

To examine whether ORL varied significantly with years of different population density, we compared frequency distributions of ORL's on the 3.5-ha plot between the high density year (1983) and the low density years $(1982,1984,1985)$. ORL's for both species were significantly smaller at high than at low density (Table 1). The proportions of individuals with large ORL (more than $100 \mathrm{~m}$ ) at low, moderate, and high densities were $22-24,16$, and $7 \%$, respectively, in voles and $38-44,18$, and $13 \%$, respectively, in mice. The proportion of individuals with smallest ORL (less than $40 \mathrm{~m}$ ) increased with population size from 22 to $45 \%$ in voles and from 8 to $42 \%$ for mice (Table 1). Both voles and mice hold larger home ranges in the years of low density and smaller in the year of high density. Significant differences were found between the two species, ORL's of mice being shifted towards larger sizes ( $K$-S test; high density: $D=0.255, p<0.001$; moderate: $D=0.190, p<0.001$; low: $D=0.255, p=0.02$, 3.5-ha plot; $D=0.249, p<0.001,12$-ha plot). Thus, independent of the population density, mice supported larger home ranges than did voles (Table 1).

ORL was estimated with short, 7-day trapping sessions. The total observed range of movements (TRL) calculated as the maximum distance between captures of an individual over the time of its presence on the plot varied in particular years from 56 to $160 \mathrm{~m}$ for voles and from 70 to $170 \mathrm{~m}$ for mice. Plot size (3.5 and 12 ha) had no significant effect on the estimate of TRL ( $K-S$ test; voles: $D=0.152$, $p=0.129$; mice: $D=0.196, p=0.388$ ). TRL was larger in the years of low than of high densities (voles: $D=0.437, p<0.001$, mice: $D=0.540, p<0.001$ ). The proportion of individuals with TRL exceeding $100 \mathrm{~m}$ decreased with population size. For voles it was $45-38 \%$ at low, $35 \%$ at moderate, and $12 \%$ at high density. 
The respective values for mice were $65-60,45$, and $20 \%$. TRL was significantly smaller for voles than for mice on all the plots (high density: $D=0.29, p<0.001$; moderate density: $D=0.21, p<0.001$; low density: $D=0.25, p=0.04$ on 3.5-ha plot, $D=0.18, p=0.03$ on 12-ha plot). Differences between ORL and TRL were higher in the low density years than in the year of high density. The TRL increased with the length of time on the plot (Fig. 4). This increase was highest at low population density and lowest, not significant in voles, at high population density. TRL can be an effect of home range shifts by individuals, or an effect of different number of captures, or differential ORL of individuals with different lengths of time on the plot when marked. The original ORL (at the first capture after marking) for individuals with different lengths of time on the plot did not show significant differences. Instead, TRL depended on the length of time on the plot, rather than on the number of captures. Two-way ANOVA gives the following effects

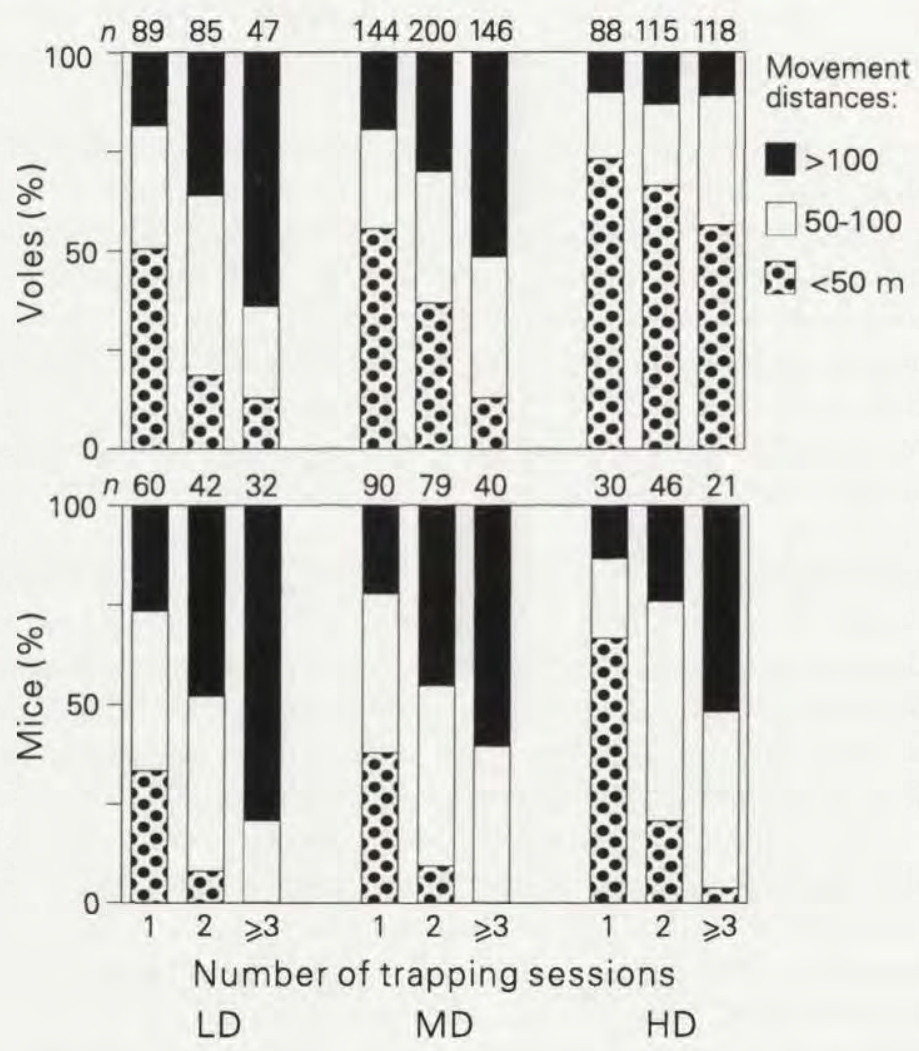

Fig. 4. Percentage distributions of the total movement distance of individuals present on the study plots over 1,2 , and 3 or more trapping series in the years of low (LD), moderate (MD) and high (HD) population densities. Numbers above bars indicate sample sizes. Significant increases in the movement distance with time: voles, moderate density: $\chi^{2}=45.84, p<0.001$, low density: $\chi^{2}=38.20$, $p<0.001$; mice, high density: $\chi^{2}=12.12, p=0.02$, moderate density: $\chi^{2}=24.58, p<0.001$, low density: $\chi^{2}=17.78, p<0.001$. 
for voles at low, moderate and high densities: time: $F=15.6, \mathrm{df}=220, p<0.001$; $F=22.3, \mathrm{df}=489, p<0.001 ; F=0.42, \mathrm{df}=320, p=0.661$; captures: $F=1.13$, $p=0.335 ; F=0.54, p=0.658 ; F=3.8, p=0.011$. For mice, time: $F=10.9, \mathrm{df}=133$, $p<0.001 ; F=10.2, \mathrm{df}=208, p<0.001 ; F=3.4, \mathrm{df}=136, p=0.035$; captures: $F=1.49, p=0.223 ; F=1.52, p=0.216 ; F=2.5, p=0.04$.

\section{Home range shift}

The distance between the last and the first capture (LFD) as well as the distance of the shift of home range centre between successive trapping sessions (CCD) varied during the study with density of rodents (One-way ANOVA; voles: $F=12.5$, $\mathrm{df}=817, p<0.001$ for LFD, $F=14.5, p<0.001$ for CCD; mice: $F=3.5$, $\mathrm{df}=299$, $p<0.03$ for LFD, $F=3.0, p=0.04$ for CCD). The LFD can be an effect of a change in location of individuals as well as an effect of differences in home range size. It was found that LFD were correlated with CCD (for voles at low, moderate and high densities: $r=0.941$, $\mathrm{df}=154, p<0.001 ; r=0.909$, $\mathrm{df}=404, p<0.001$; $r=0.885, \mathrm{df}=327, p<0.001$, respectively; and for mice: $r=0.936, \mathrm{df}=63$, $p<0.001 ; r=0.908, \mathrm{df}=149, p<0.001 ; r=0.818, \mathrm{df}=80, p<0.001)$ and not with home range sizes (voles: $r=0.144, p=0.171 ; r=0.095, p=0.55 ; r=0.123$, $p=0.34$; mice: $r=0.153, p=0.227 ; r=0.110, p=0.177 ; r=0.177, p=0.117$ ).

The mean LFD in different trapping sessions varied from 19 to $70 \mathrm{~m}$ in voles and from 35 to $82 \mathrm{~m}$ in mice. The mean CCD varied from 16 to $60 \mathrm{~m}$ in voles and from 31 to $80 \mathrm{~m}$ in mice. In a step wise multiple regression of mean CCD on: (1) the annual peak density, (2) density in a trapping session in question and (3) the index of season (May, June, and August), annual peak density entered the model first (voles: $R^{2}=82 \%, \mathrm{df}=19, p<0.001$; mice: $R^{2}=73 \%$, df $=19, p<0.001$ ). Only additior of the index of season increased the coefficient of determinant (by $2 \%$ for voles ard by $6 \%$ for mice).

The analysis of home range shifts calculated by using both indices did not show a signifcant effect of the plot size on the estimate of the shift of home anges of both rocents ( $K-S$ test; voles: $D=0.116, p=0.999$ for LFD, $D=0.113, p=0.999$ for CCL; mice: $D=0.154, p=0.999$ for LFD, $D=0.139, p=0.999$ for CCD). Most voles and mice shifted their home ranges by significantly shorter distances in the high than in the low density years (Tables 2 and 3). As the density increased, the proportion of individuals with a home range shift greater than $100 \mathrm{~m}$ declined from 14 to $1 \%$ in voles and from 19 to $6 \%$ in mice (Tables 2 and 3). Concurrently, the proportion of individuals with home range shift less than $15 \mathrm{~m}$ (not shifting their hone ranges?) increased from 18 to $55 \%$ in voles and from 14 to $19 \%$ in mice. Mice shfted their home ranges to greater distances than did voles $(K-S$ test; for LFD: $D=0.292, p<0.001$ at high, $D=0.219, p<0.001$ at moderate, $D=0.336$, $p=0.02$ at low density on 3.5-ha plot, and $D=0.240, p<0.001$ at low density on 12-ha pbt; and for CCD: $D=0.385, p<0.001$ at high, $D=0.160, p<0.001$ at moderat, $D=0.207, p=0.02$ at low density on 3.5 -ha plot, and $D=0.186, p=0.03$ at low density on 12-ha plot) (Tables 2 and 3 ). 
Table 2. Percentage distributions of the shifts of home ranges calculated as a distance between the site of the last capture in the preceding trapping series and the site of the first capture in the next trapping series (LFD) at different population densities on plots of different sizes. Differences between distribution at low and high density were significant ( $K-S$ test; voles: $D=0.495, p<0.05$; mice: $D=0.485, p<0.05$ ). $n$ - sample sizes.

\begin{tabular}{|c|c|c|c|c|c|c|c|c|c|c|}
\hline \multirow{2}{*}{ Species } & \multirow{2}{*}{ Plot } & \multirow{2}{*}{ Density (ha) } & \multirow{2}{*}{$n$} & \multicolumn{7}{|c|}{ Shifts of home ranges (LED) } \\
\hline & & & & 25 & 50 & 75 & 100 & 125 & 150 & $>150 \mathrm{~m}$ \\
\hline \multirow[t]{4}{*}{ Voles } & 3.5 & High & 327 & 74.6 & 19.9 & 1.5 & 1.5 & 1.2 & 0.9 & 0.3 \\
\hline & & Low & 101 & 30.3 & 39.4 & 13.6 & 3.0 & 4.5 & 1.5 & 7.6 \\
\hline & 6 & Moderate & 390 & 49.5 & 25.8 & 7.0 & 8.0 & 3,3 & 2.3 & 4.3 \\
\hline & 12 & Low & 157 & 29.7 & 31.0 & 14.8 & 7.7 & 3.2 & 2.6 & 11.0 \\
\hline \multirow[t]{4}{*}{ Mice } & 3.5 & High & 82 & 48.8 & 37.5 & 7.5 & 2.5 & 0.0 & 0.0 & 3.8 \\
\hline & & Low & 69 & 15.9 & 26.1 & 17.4 & 14.5 & 13.0 & 4.4 & 8.7 \\
\hline & 6 & Moderate & 150 & 29.3 & 31.3 & 14.7 & 7.3 & 7.3 & 4.7 & 5.3 \\
\hline & 12 & Low & 104 & 21.1 & 28.2 & 16.9 & 9.9 & 7.0 & 2.8 & 14.1 \\
\hline
\end{tabular}

Table 3. Percentage distributions of home range shifts calculated as a distance between geometric centres in two successive trapping series (CCD), at different population densities on plots of different sizes. Differences between distribution at low and high density were significant ( $K-S$ test; voles: $D=$ $0.532, p<0.001$; mice: $D=0.309, p<0.05) . n$ - sample sizes.

\begin{tabular}{|c|c|c|c|c|c|c|c|c|c|c|}
\hline \multirow{2}{*}{ Species } & \multirow{2}{*}{ Plot } & \multirow{2}{*}{ Density (ha) } & \multirow{2}{*}{$n$} & \multicolumn{7}{|c|}{ Shifts of home ranges (CCD) } \\
\hline & & & & 25 & 50 & 75 & 100 & 125 & 150 & $>150 \mathrm{~m}$ \\
\hline \multirow[t]{4}{*}{ Voles } & 3.5 & High & 327 & 82.3 & 14.7 & 1.5 & 0.6 & 0.3 & 0.3 & 0.3 \\
\hline & & Low & 101 & 37.9 & 30.3 & 15.2 & 3.0 & 4.5 & 1.5 & 7.6 \\
\hline & 6 & Moderate & 390 & 52.3 & 26.8 & 9.5 & 4.3 & 2.3 & 1.0 & 4.0 \\
\hline & 12 & Low & 157 & 43.9 & 21.9 & 14.8 & 5.8 & 5.8 & 2.7 & 5.2 \\
\hline \multirow[t]{4}{*}{ Mice } & 3.5 & High & 82 & 48.8 & 35.4 & 7.3 & 2.4 & 2.4 & 1.2 & 2.4 \\
\hline & & Low & 69 & 34.8 & 26.1 & 13,0 & 8.7 & 7.2 & 3.0 & 7.2 \\
\hline & 6 & Moderate & 150 & 42.0 & 26.0 & 13.3 & 6.7 & 4.7 & 4.0 & 3.3 \\
\hline & 12 & Low & 104 & 32.4 & 23.9 & 16.9 & 7.0 & 4.2 & 2.8 & 12.7 \\
\hline
\end{tabular}

Shifts of home ranges between successive trapping sessions can be directional or non-directional and rodents may remain longer at the same sites. The summation of directional shifts of home ranges, even if these are small shifts, causes that rodents leave the study area which may be their natal sites and become emigrants. The total distance of the shifts, calculated for individuals present in at least 3 trapping sessions, was shorter at high than at low densities ( $K$ - $S$ test; voles: $D=0.389, p<0.001$; mice: $D=0.563, p=0.03$ ). At high density, mice moved longer distances than voles $(D=0.449, p=0.04$ ) (Fig. 5). The total distance of shift was significantly higher than shift between successive trapping sessions, in 


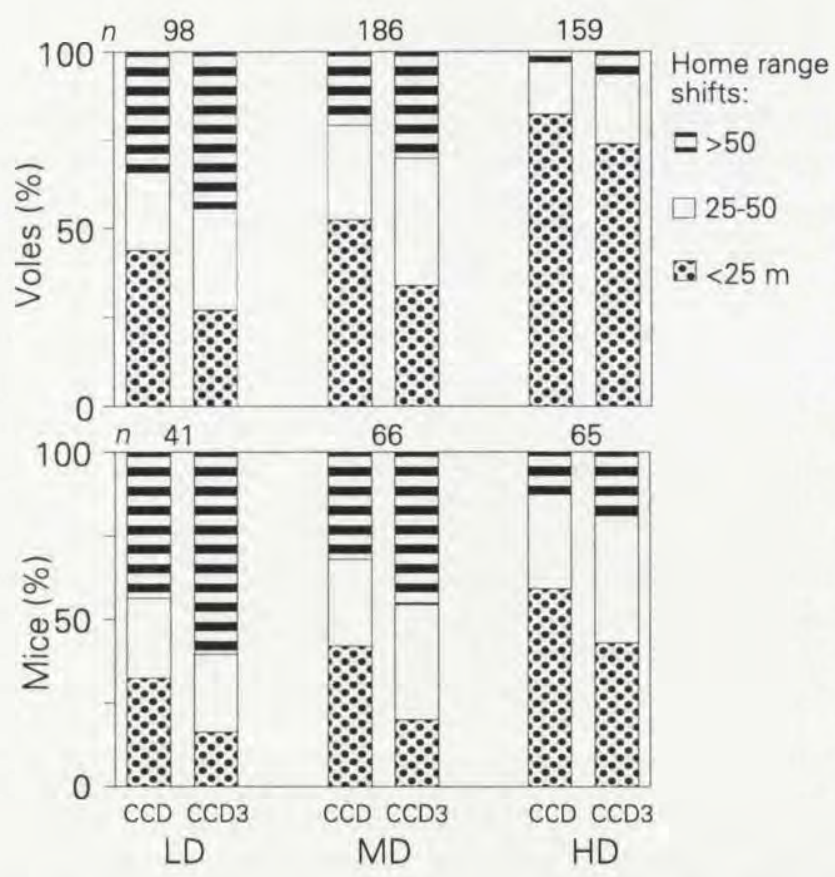

Fig. 5. Comparison of percentage distributions of home range shifts (CCD) between successive trapping series ( 1 and 2, 2 and 3 ) and the total distance of shift between trapping series 1 and 3 (CCD3). Numbers above bars indicate sample sizes. The total distance of the shift was significantly longer than the shift between successive trapping series at low (LD) and moderate (MD) densities $(K-S$ test; voles: $D=0.242, p<0.001$ and $D=0.208, p<0.001$, respectively; mice: $D=0.356, p<0.05$ and $D=0.303, p<0.05)$. HD - high density of populations.

the years of low and moderate population densities. In the high density year, the total distances of shift did not significantly differ from the shifts between successive trapping sessions (Fig. 5). To estimate whether home range shifts occur at random or directionally, we compared home range shifts of individual rodents between successive trapping sessions with the total distance of their shift. A net shift longer than $75 \%$ of the sum of successive shifts was considered as a directional shift. When shifts between successive trapping sessions were longer than the total shift, we considered them to involve occasional sallies. In the years of low and moderate densities, about $15 \%$ of voles and $20 \%$ of mice temporarily shifted home range centres by more than $50 \mathrm{~m}$ and finally returned to their previous home ranges. Such sallies practically did not exist in the high density year $(0.5 \%$ in both species). Nonetheless, $60 \%$ of the voles and $70 \%$ of the mice at low density, and $50 \%$ of the voles and $65 \%$ of the mice at moderate density, but only $20 \%$ of the voles and $30 \%$ of the mice at high density moved directionally within the study area. Thus, in the high density year, home range shifts of both species were not only shorter but also non-directional. 


\section{Site tenacity and dispersal}

Differences in the spatial behaviour of rodents observed between the years of low and high densities concerned both the distance of home range shift and the size of home ranges. Thus, the absolute distance of the shift of a home range centre alone does not provide evidence for abandoning the home range. Only individuals that shifted the centres of their home ranges to a distance longer than ORL in the preceding trapping session were designated as abandoning their home ranges. In both species the proportion of individuals abandoning their home ranges was higher in the low density years than in the high density year and these differences were larger for voles than for mice (Table 4).

Table 4. Proportions of individuals staying in the same home range, partly shifting it, and abandoning it. Differences between distribution at low and high density were significant (voles: $\chi^{2}=70.4, p<0.001$; mice: $\chi^{2}=11.7, p<0.001$ ). $n$ - sample sizes.

\begin{tabular}{llrccc}
\hline \multirow{2}{*}{ Species } & Density (ha) & $n$ & \multicolumn{3}{c}{ Percentage } \\
\cline { 4 - 6 } & & & Staying & Shifting & Abandoning \\
\hline \multirow{2}{*}{ Voles } & High & 327 & 84 & 9 & 7 \\
& Low & 157 & 50 & 12 & 38 \\
& Moderate & 400 & 57 & 19 & 24 \\
\multirow{3}{*}{ Mice } & High & 82 & 54 & 30 & 16 \\
& Low & 86 & 45 & 15 & 40 \\
& Moderate & 132 & 53 & 17 & 30 \\
\hline
\end{tabular}

As a result of differential tendencies to abandon their home ranges observed in the years of high and low densities, rodents can move deferentially beyond the study plot. Between successive trapping sessions $60 \%$ of the voles disappeared in the years of low density and $44 \%$ in the year of high density. The respective figures for mice were 70 and $60 \%$. Among the rodents disappearing from the study plot new individuals prevailed. The proportion of new individuals that disappeared declined with increasing density, and it was lower in voles than in mice (Fig. 6). Differential mobility of rodents in the years of low and high densities can be accompanied by differential frequency of immigration to the study plots. In each trapping session, among individuals trapped for the first time there were not only young weaned between trapping sessions but also adult individuals, more than 2 -month old. These individuals were considered as immigrants. The proportion of immigrants in the total number of individual $s$ appearing between successive trapping sessions in the vole population was $34 \%$ in the years of low and $14 \%$ in the year of high density. The respective figures for the mouse population were 40 and $30 \%$ (Fig. 6). 


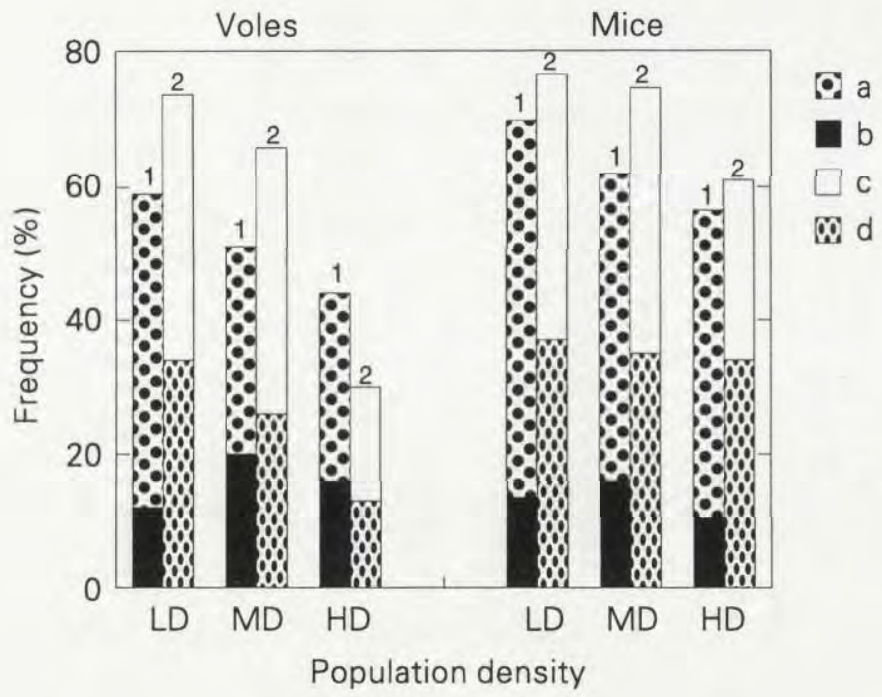

Fig. 6. Percentages of disappearing individuals (1) subdivided into those captured for the first time (a) and those already marked (b) in populations. Percentages of individuals recruited to the population (2) subdivided into those born between successive trapping series (c) and immigrants (d) in populations. See Fig. 4 for explanation of population density symbols.

Table 5. Percentage distributions of May-August recruits with various length of time on the plot. The lenght of time on the plot was expressed as numbers of trapping sessions. The proportion of recruits that emigrated after marking was significantly higher in mice than in voles (at high density: $\chi^{2}=19.68, p<0.001$, at moderate density: $\chi^{2}=30.06, p<0.001$, at low density: $\chi^{2}=4.60, p<0.05$ on 3.5 -ha plot and $\chi^{2}=4.78, p<0.05$ on 12 -ha plot).

\begin{tabular}{|c|c|c|c|c|c|c|}
\hline \multirow{2}{*}{ Species } & \multirow{2}{*}{ Plot } & \multirow{2}{*}{ Density (ha) } & \multirow{2}{*}{$n$} & \multicolumn{3}{|c|}{ Numbers of trapping sessions } \\
\hline & & & & 1 & 2 & 3 or more \\
\hline \multirow[t]{4}{*}{ Voles } & 3.5 & High & 415 & 23.0 & 41.0 & 36.0 \\
\hline & & Low & 118 & 38.0 & 45.0 & 17.0 \\
\hline & 6 & Moderate & 600 & 33.0 & 40.0 & 27.0 \\
\hline & 12 & Low & 230 & 39.0 & 43.0 & 19.0 \\
\hline \multirow[t]{4}{*}{ Mice } & 3.5 & High & 243 & 46.5 & 43.0 & 10.5 \\
\hline & & Low & 85 & 50.0 & 37.0 & 13.0 \\
\hline & 6 & Moderate & 288 & 47.5 & 34.5 & 18.0 \\
\hline & 12 & Low & 133 & 49.0 & 33.0 & 18.0 \\
\hline
\end{tabular}

Loss rates measure both, the mortality and emigration of rodents. Emigration rates of recruits were higher in mice than in voles (Table 5). Voles remained on the plot for a longer time than mice. Moreover, the residency of voles increased 


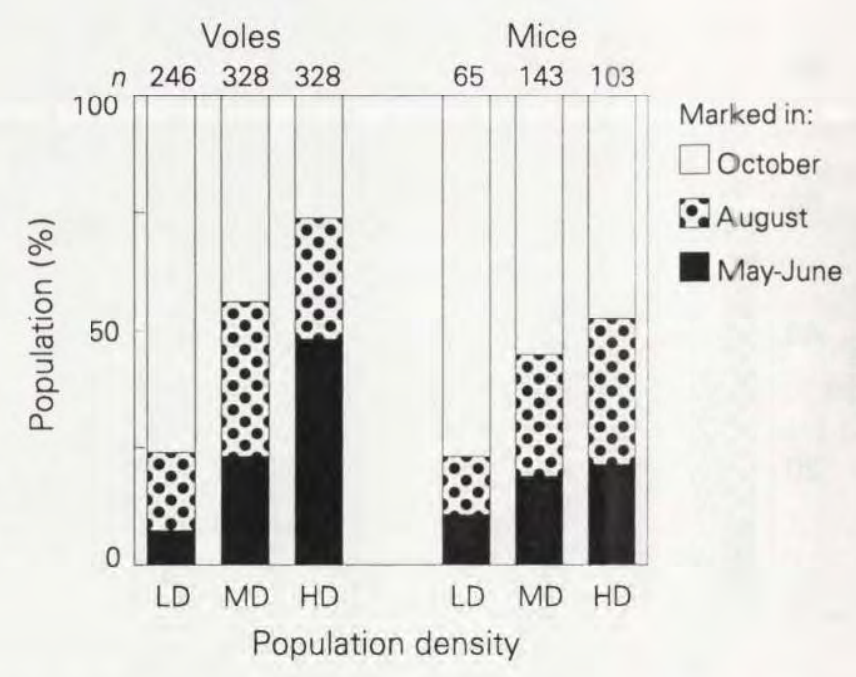

Fig. 7. Age structure of the population in autumns of the years with different population densities. Numbers above bars indicate sample sizes. Age of rodent populations was significantly "older" at high than at low population densities $\left(\chi^{2}=155.75, p<0.001\right.$ for voles, $\chi^{2}=12.32, p<0.001$ for mice). See Fig. 4 for explanation of population density symbols.

with the population density (Table 5). Comparing the presence of the same individuals between the 3.5-ha plot and the 12-ha plot, only $20 \%$ of the mice and $25 \%$ of the voles classified as emigrants on the 3.5-ha plot settled in the nearby neighbourhood (on the 12-ha plot), whereas the other individuals disappeared.

Differences in emigration rate between the years of high and low densities may cause differences in the age structure of the population on the plot, and if it is assumed that emigrants incur higher mortality, also in the whole forest. The age structure of the populations of both species was estimated in the autumns of the years with different population densities. The proportions of individuals marked in early and late summer and in autumn showed significant differences between the years of high and low densities (Fig. 7). Distributions of body mass also varied with density in both species, being shifted towards higher body mass at high density ( $K$-S test; voles, low-high density: $D=0.444, p<0.001$; medium-high density: $D=0.410, p<0.001$; low-medium density: $D=0.267, p<0.001$; mice, low-high density: $D=0.413, p<0.001$; medium-high density: $D=0.404, p<0.001$; low-medium density: $D=0.230, p=0.05$ ). The proportions of voles with body mass less than $17 \mathrm{~g}$, at low, moderate, and high densities were $66-51 \%, 48-40 \%$, and $23 \%$. The proportions of mice with body mass less than $25 \mathrm{~g}$, were, respectively, $80-60 \%, 51-45 \%$, and $21 \%$. Thus the proportion of young decreased with population size. With increasing population density, low mobility and high site tenacity delayed the maturation of young individuals and reduced recruitment of new individuals, and the populations of both species grew older. 


\section{Discussion}

Food supply frequently limits population density and reproduction, at least in temperate environment (Flowerdew 1985, Boutin 1990, Pucek et al. 1993, Jędrzejewski and Jędrzejewska 1996, Wolff 1996). Indeed, we found that numbers of breeding males and females were highest in the high density year and lowest in the low density years. High numbers of rodents in 1983 were preceded by heavy mast crop and by winter breeding, also observed in other parts of Europe, and numbers of these species in the other years were also correlated with food abundance (Pucek et al. 1993). In 1983, spring numbers of mice and voles were high. However, population of voles grew faster and reached a higher and earlier annual peak suggesting a stronger effect of kinship and familiarity on population dynamics (Ylönen et al. 1995) in voles than in mice. High spring numbers in 1989 was caused by early breeding following an unusually early spring and accelerated growth of vegetation (Rajska-Jurgiel 1992). The onset of breeding coincides with the beginning of phenological spring (Bujalska 1983, 1985, Rajska-Jurgiel 1992), and the survival of spring generations depends on food supply (Bujalska 1975, Banach 1986). However, annual peak densities did not depend on the spring density, except in 1983. Instead, annual peaks were correlated with spring-summer home range sizes and home range shifts. Although the food availability and predation are the ultimate factors that determine the level of species abundance, the pattern of changes in numbers and winter mortality rates are not fully explained by food supply and predation alone (Pucek et al. 1993, Jędrzejewski and Jędrzejewska 1996).

Movement patterns of both species varied over the study period. Changes in mobility were associated with long-term rather than seasonal changes in numbers of rodents. The largest home ranges for both species were observed in the years of low numbers. The year-to-year changes in the home range size concerned mature males and females, as well as immature individuals of both species (E. Rajska-Jurgiel and M. Mazurkiewicz, in prep.). Changes in home range sizes with variation in the density of forest rodents were observed by many authors (Zejda and Pelikan 1969, Mazurkiewicz 1981, Wolff 1985, Adler and Wilson 1987, Johnson 1988, Bujalska and Grüm 1989). Both, home range size and the population density are related to the resource abundance, however defined (Attuquayefio et al. 1986, Bondrup-Nielsen 1986, Boutin 1990, Jones 1990). Spatial behaviour of animals primarily depends on the availability of necessary resources. A strategy increasing fitness (survival and breeding) is to possess the largest amount of resources within the smallest area. That minimizes the time spent outside the nest, risk of predation and infanticide (Schoener 1971, Krebs 1980, Wolff and Cicirello 1989, Wolff 1993). In resource rich patches, where rodent densities are typically higher, the home ranges can be smaller (Karaseva and Ilyenko 1957, Lavrova and Andreeva 1960, Nikitina and Merkova 1963, Wolff 1985, Attuquayefio et al. 1986, Jones 1990). Home range size declines with a food addition (Smith 1971, Bujalska 1975, 1985, 
Andrzejewski and Mazurkiewicz 1976, Ims 1987, Boutin 1990). With resource deficiencies, however defined, there is an increase in the home range size and mobility of rodents (Bondrup-Nielsen and Karlsson 1985, Attuquayefio et al. 1986, Bondrup-Nielsen 1986, Korn 1986, Wolff and Cicirello 1990, Rajska-Jurgiel 1992, Salsbury and Armitage 1994).

Year-to-year changes in home range sizes were accompanied by changes in the distance of home range shifts. In the low density years, the total range of movements significantly increased with time. Both the shifts between successive trapping sessions and the total distance of shift increased with increasing home range sizes, and were highest in the low density years. Year-to-year changes in the home range shift concerned mature males and females, as well as immature individuals (E. Rajska-Jurgiel and M. Mazurkiewicz, in prep.). More rodents abandoned their home ranges in the years of low than in the year of high density. In non-cyclic populations, the rate of dispersal is typically higher at low than at high densities (Mazurkiewicz and Rajska-Jurgiel 1975, Jannett 1978, Jones et al. 1988, Wolff et al. 1988, Bujalska and Grüm 1989, Jones 1989, Wolff and Cicirello 1990, Hansson 1991, Chistova 1995, Lukyanov 1995), as a consequence of resource limitation as well as competition for mates or space to breed. Dispersal rates decline with increasing availability of resources. Superabundant food supply (seed crop, supplemental feeding) inhibit emigration and allow for immigration into food rich patches (Boutin 1990, Brandt 1992, Löfgren et al. 1996). As the territory size is a function of habitat quality (Bujalska 1975, 1985, Ostfeld 1985, Bondrup-Nielsen 1986, Jones 1990), good food conditions relax competition for space (Ims 1987, Ylönen et al. 1988). Dispersal distance depends on the home range size and exploration rates (Johnson 1988, Jones 1989, Wegner and Merriam 1990). Resource deficiency, however defined, causes an increase in dispersal rates (Jones et al. 1988, Wolff and Cicirello 1990, Brandt 1992). Although dispersal increases the risk of predation, the chance of finding resources is also increased. If densities reflect the food conditions, high dispersal rates at low density may be a strong stabilizing factor against food shortage. Another explanation is that at low numbers rodents disperse just because they can (Bujalska and Grüm 1995, Grüm and Bujalska 1995, Plesner-Jensen 1996).

We conclude that the spatial behaviour of both, the bank voles and the yellow-necked mice is highly flexible and can change under various environmental conditions. At high density, movement ranges of voles were similar to those found in confined populations (Ylönen et al. 1988, Bujalska and Grüm 1989). At low density, they were similar to those observed in the patchy field-forest landscape (Kozakiewicz and Szacki 1995).

Assuming that the spatial behaviour of a single individual depends on the available resources, a question arises whether spatial behaviour of rodents can be responsible for determining population dynamics? The choice: stay in the natal area or leave it can be of crucial importance to the regulation of population numbers. Local population density largely depends on residency of rodents 
(Andrzejewski 1963, Petrusewicz 1983, Mazurkiewicz and Rajska-Jurgiel 1987, Gliwicz 1989). We have shown that site tenacity of the two species varied with changes in home range size. As the mobility increased, the number of rodents disappearing from the study area increased, although free space was more available. High rate of movements and dispersal observed at low densities can increase mortality from predation (Erlinge et al. 1984, Hansson and Henttonen 1988), and affect the total numbers over larger forest areas. Low mobility of rodents led to their increased site tenacity and to a rapid increase in the density of, at least, local populations.

Resource deficiency accounts for increased mobility, aggressiveness and territorial tendencies in animals (Bondrup-Nielsen 1985, Ims 1987, Ostfeld 1985, Anderson 1989, Hansson 1991, Brandt 1992). High mobility of rodents caused high emigration rates and early juvenile maturation. At low density, dispersers can easily find a place to breed because of a good supply of vacant space and frequent movements of residents. Low mobility and high site tenacity inhibited juvenile maturation. At high density, early juvenile maturation is suppressed (Adamczewska 1961, Bujalska 1970, Bobek 1971, Montgomery 1980, Gipps 1985, Montgomery and Gurnell 1985, Bujalska and Grüm 1989). High spring numbers of breeding females give rise to recruitment of large numbers of juveniles and rapid filling of vacant space early in the season. High densities of the year-born young inhibit their dispersal (Mazurkiewicz and Rajska 1975, Goundie and Vessey 1986, Bujalska and Grüm 1995, Grüm and Bujalska 1995). As a result of lack of vacant space and high site tenacity of residents, a chance for finding a place for breeding is small. The recruitment of young declines in summer with increasing population numbers and cessation of breeding.

Both, population density and maturation rates were effects of changing movement patterns of rodents. Reduced mobility, increased site tenacity, and increased population density accounted for cessation of breeding and reduced juvenile recruitment in late summer. As a result, local populations showed different age structures in autumn. "Old age structure" may account for high winter mortality observed in the high density year. Under different environmental conditions, the same species of rodent can show "cyclic" or "non-cyclic" population dynamics (Hansson and Henttonen 1985, Henttonen et al. 1985, Taitt and Krebs 1985). One of these species is the bank vole. The direct proximate reasons for the peak and crash years are still under debate (Hornfeldt 1994, Körpimaki et al. 1994, Löfgren 1995, Jędrzejewski and Jędrzejewska 1996, Hanski and Henttonen 1996, Krebs 1996). However, changes in the proportion of breeders, maturation rates, shortening of the breeding season, lack of juvenile recruitment, and old age structure, are surprisingly similar to those described above.

Independent of their population densities, voles and mice differed in their spatial behaviour. Species living on more limited food resources should hold larger home ranges. Home ranges of mice were larger than those of voles. Home range size of the species living on more limited food resources should be more affected 
by changes in food supply. We found that year-to-year differences in home range size were greater for mice, more dependent on specific food resources (Angelstam et al. 1987) than for less food selective voles. Maturation rates of the species restricted in maturation by vacant space supply rather than by food availability should be more affected by density. We found that year-to-year differences in maturation rates were greater for voles than mice. If competition for food resources is the main reason for dispersal then species depending on scarcer resource should be more prone to disperse. Mice moved longer distances and more often abandoned their home ranges than did voles. Also more mice than voles emigrated from and immigrated into the study plots. If competition for place to breed is the main reason for dispersal then dispersal rates of species with lower maturation rates should be more affected. Year-to-year differences in the magnitude of home range shifts and in site tenacity were larger in voles than mice. Increase in the time of residency and inhibition of juvenile maturation as a result of the low mobility of rodents in 1983, were much greater in voles than in mice. However, mice were only locally abundant and patchily dispersed over the forest. In another locality of the same forest, the density of voles was equally high and the density of mice was much lower (Mazurkiewicz and Rajska-Jurgiel 1987). In the low density year mice, but not voles, were almost absent from that plot. Thus, according to habitat saturation hypothesis (Bujalska and Grüm 1995, Grüm and Bujalska 1995, Löfgren 1995, Plesner-Jensen 1996) mice simply "could" move farther than voles, at least into a dispersal sink.

The natural heterogeneity of each landscape, even of continuous forests, and habitat selection of animals means that the environment of the species is heterogeneous. Patchy distribution of resources results in increasing animal mobility (Merriam and Lanoue 1990, Wegner and Merriam 1990, Szacki and Liro 1991, Rajska-Jurgiel 1992, Kozakiewicz and Szacki 1995) which increases the chance of encountering resources, although increases the predation risk through exposure. Under circumstances of spatial and temporal variability in the habitat quality, natural selection favours exploration and dispersal behaviour (Stenseth and Lidicker 1992). Natural fragmentation of the forest habitat, resulting from spatial heterogeneity of plant cover, means that the spatial distribution of food resources is more uneven for seed-eating mice than for voles. It is also probably more patchy in poor than in good food years. The availability of shelters, important to bank voles, is less variable in time. Nonetheless spatial differentiation of the habitat in terms of the availability of good vacant shelters and nest places is higher at low than high density. Differences in food requirements and in predictability of the resource distribution have an effect on site tenacity and dispersal of the two species. Narrow food/habitat preference in mice is offset by their lower vulnerability to predation. High mobility in search of food, frequent shifting of home ranges, and high dispersal capabilities are adaptations to natural fragmentation of the habitat and a specific preadaptation of this species to landscape fragmentation. 
Acknowledgements: We acknowledge the comments by the staff of the Department of Vertebrate Ecology and three anonymous referees. Our study has been financially supported by the Institute of Ecology, Polish Academy of Sciences.

\section{References}

Adamczewska K. A. 1961. Intensity of reproduction of the Apodemus flavicollis (Melchior, 1834) during the period 1954-1959. Acta Theriologica 5: 1-21.

Adamczewska-Andrzejewska K., Bujalska G. and Mackin-Rogalska R. 1981. Changes in numbers of Microtus arvalis (Pall.) and Apodemus flavicollis (Melch.) of chosen crop fields. Polish Ecological Studies 7: 175-192.

Adler G. H. and Wilson M. L. 1987. Demography of a habitat generalist the white-footed mouse in a heterogeneous environment. Ecology 68: 1785-1796.

Alibhai S. K. and Gipps J. H. W. 1985. The population dynamics of bank voles. Symposia of the Zoological Society of London 55: 277-313.

Anderson P. A. 1989. Dispersal in rodents: a resident fitness hypothesis. Special Publications, American Naturalist 6: 1-90.

Andrzejewski R. 1963. Processes of incoming, settlement and disappearance of individuals and variations in the number of small rodents. Acta Theriologica 7: 169-213.

Andrzejewski R. 1975. Supplementary food and winter dynamics of bank voles populations. Acta Theriologica 20: 23-40.

Andrzejewski R. and Babińska-Werka J. 1986. Bank vole populations: are their densities really high and individual home ranges small? Acta Theriologica 31: 407-420.

Andrzejewski R. and Mazurkiewicz M. 1976. Abundance of food supply and size of bank voles home range. Acta Theriologica 21: 237-256.

Angelstam P., Hansson L. and Pehrsson S. 1987. Distribution borders of field mice Apodemus: the importance of seed abundance and landscape composition. Oikos 50: 123-130.

Apeldoorn R. C., van Oostenbrink W. T., van Winden A. and van der Zee F. F. 1992. Effects of habitat fragmentation on the bank vole, Clethrionomys glareolus in an agricultural landscape. Oikos 65: $265-274$,

Attuquayefio D. K., Gorman H. L. and Wolton R. J. 1986. Home range sizes in the wood mouse Apodemus sylvaticus: habitat, sex and seasonal differences. Journal of Zoology, London 210: 45-53.

Banach K. 1986. The effect of increased food supply on the body growth rate and survival of bank voles in an island population. Acta Theriologica 31: 45-54.

Bäumler W. 1981. Zur Verbreitung, Ernährung und Populations dynamik der Rötelmaus (Clethrionomys glareolus) und der Gelbhalsmaus (Apodemus flavicollis) in einem Waldgebiet der Bayerischen Alpen. Anzeigezeitung Schädlingskole 54: 49-53.

Bergstedt B. 1966. Home range and movements of the rodent species, Clethrionomys glareolus and Apodemus sylvaticus in southern Sweden. Oikos 17: 150-157.

Bobek B. 1971. Influence of population density upon rodent production in a deciduous forest. Annales Zoologici Fennici 8: 137-144.

Bondrup-Nielsen S. 1985. An evaluation of the effects of space use and habitat patterns on dispersal in small mammals. Annales Zoologici Fennici 22: 373-383.

Bondrup-Nielsen S. 1986. Demography of Clethrionomys gapperi in different habitats. Canadian Journal of Zoology 65: 277-283.

Bondrup-Nielsen S. and Karlsson F. 1985. Movements and spatial patterns in populations of Clethrionomys species: a review. Annales Zoologici Fennici 22: 385-392.

Boutin S. 1990. Food suplementation experiments with terrestrial vertebrates: patterns, problems, and the future. Canadian Journal of Zoology 68: 203-220. 
Brandt C. A. 1992. Social factors in imigration and emigration. [In: Animal dispersal: small nammals as a model. N. C. Stenseth and Z. L. Lidicker Jr, eds]. Chapman and Hall, London: 96-141.

Bujalska G. 1970. Reproduction stabilizing elements in an island population of Clethrionomys glareolus (Schreber, 1780). Acta Theriologica 15: 381-412.

Bujalska G. 1975. The effect of supplementary food on some parameters in an island population of Clethrionomys glareolus. Bulletin de L'Academie Polonaise de Science, serie de sciences biologiques 23: 23-28.

Bujalska G. 1983. Reproduction. [In: Ecology of the bank vole. K. Petrusewicz, ed]. Acta Theriologica 28, Supplement 1: 148-161.

Bujalska G. 1985. Fluctuation in an island bank vole population in the light of the study on its organization. Acta Theriologica 30: 3-49.

Bujalska G. and Grüm L. 1989. Social organization of the bank vole (Clethrionomys glareolus, Schreber 1780) and it's consequences: a model. Oecologia (Berlin) 80: 70-81.

Bujalska G. and Grüm L. 1995. Dispersal behaviour in female bank voles, Clethrionomys glareolus (Schreber, 1780). Polish Ecological Studies 20: 123-129.

Chętnicki W. and Mazurkiewicz M. 1994. Dispersion of the bank vole in fine- and coarse-grained mosaics of deciduous and mixed coniferous forests. Acta Theriologica 39: 127-145.

Chistova T. 1995. Spatial organization of a bank vole population in a forest-steppe oak forest. Polish Ecological Studies 20: 147-154.

Drożdż A. 1966. Food habits and food supply of rodents in beech forest. Acta Theriologica 11:363-384

Erlinge S., Goransson G., Hogstedt G., Jansson G., Liberg O., Loman J., Nilsson I. N., von Schantz T. and Sylven M. 1984. Can vertebrate predators regulate their prey? American Naturalist 123: 125-133.

Flowerdew J. R. 1976. The effect of a local increase in food supply on the distribution of woodland mice and voles. Journal of Zoology, London 180: 509-513.

Flowerdew J. R. 1985. The population dynamics of wood mice and yellow-necked mice. Symposia of the Zoological Society of London 55: 315-338.

Flowerdew J. R., Gurnell J. and Gipps J. H. W. (eds) 1985. The ecology of woodland rodents: bank voles and wood mice. Symposia of the Zoological Society of London 55: 1-418.

French N. R., Stoddart D. M. and Bobek B. 1975. Patterns of demography. [In: Small mammals, their productivity and population dynamics. F. B. Golley, K. Petrusewicz and L. Ryszkowski, eds]. Cambridge University Press, Cambridge: 73-102.

Gębczyńska Z. 1976. Food habits of the bank vole and phenological phases of plants in an oak hornbeam forest. Acta Theriologica 21: 223-236.

Gębczyńska Z. 1983. Feeding habits. [In: Ecology of the bank vole. K. Petrusewicz, ed]. Acta Theriologica 28, Supplement 1: 40-49.

Gipps J. H. W. 1985. The behaviour of bank voles. Symposia of the Zoological Society of London 55: 61-78.

Gliwicz J. 1989. Individuals and populations of the bank vole in optimal, suboptimal and insular habitats. Journal of Animal Ecology 58: 237-247.

Golley F. B., Petrusewicz K. and Ryszkowski L. (eds) 1975. Small mammals; their productivity and population dynamics. Cambridge Univesity Press, Cambridge: 1-451.

Goundie T. R. and Vessey S. H. 1986. Survival and dispersal of young white-footed mice bom in nest boxes. Journal of Mammalogy 67: 53-60.

Grüm L. and Bujalska G. 1995. Dispersal strategies in female bank voles Clethrionomys glareolus (Schreber, 1780). Polish Ecological Studies 20: 177-185.

Gurnell J. 1985. Woodland rodents communities. Symposia of the Zoological Society of London 55: $377-411$.

Hanski I. and Henttonen H. 1996. Predation on competing rodent species: a simple explanation of complex patterns. Journal of Animal Ecology 65: 220-232.

Hansson L. 1971. Small rodent food, feeding and population dynamics. A comparison between granivorous and herbivorous species in Scandinavia. Oikos 22: 183-198. 
Hansson L. 1985. The food of bank voles, wood-mice and yellow-necked mice. Symposia of the Zoological Society of London 55: 141-168.

Hansson L. 1991. Dispersal and connectivity in metapopulation. Biological Journal of the Linnean Society 42: 89-103.

Hansson L. and Henttonen H. 1985. Gradients in density variations of small rodents: the importance of latitude and snow cover. Oecologia (Berlin) 67: 394-402.

Hansson L. and Henttonen H. 1988. Rodent dynamics as community processes. Trends in Ecology Evolution 3: 195-200.

Henttonen H., McGuire A. D. and Hansson L. 1985. Comparisons of amplitudes and spectral analysis of density variation in long-term sets of Clethrionomys species. Annales Zoologici Fennici 22: 221-228,

Holišova V. 1971. The food of Clethrionomys glareolus at different population dynamics. Acta Scientiarium Naturalium Academiae Bohemos/slovacae, Brno 5: 1-43.

Hornfeldt B. 1994. Delayed density dependence as a determinant of vole cycles. Ecology 75: 791-806.

Ims R. A. 1987, Responses in spatial organization and behaviour to manipulations of the food resources in the vole Clethrionomys rufocanus. Journal of Animal Ecology 56: 585-596.

Jannett F. J., Jr 1978. The density-dependent formation of extended maternal-families of the montane vole Microtus montanus nanus. Behavioral Ecology and Sociobiology 3: 245-263.

Jensen T. S. 1982a. Seed production and outbreaks of non-cyclic rodent populations in deciduous forests. Oecologia (Berlin) 54: 184-192.

Jensen T. S. 1982b. Habitat distribution, home range and movements of rodents in mature forest and reforestation. Annales Zoologici Fennici 171: 305-307.

Jędrzejewski W. and Jędrzejewska B. 1996. Rodent cycles in relation to biomass and productivity of ground vegetation and predation in the Palearctic. Acta Theriologica 41: 1-34.

Johnson M. J. 1988. Exploratory behavior and dispersal: a graphical model. Canadian Journal of Zoology 6: 2325-2328.

Jones E. N. 1990. Effects of forage availability on home range and population density of Microtus pennsylvanicus. Journal of Mammalogy 71: 382-389.

Jones W. T. 1989. Dispersal distance and the range of nighty movements in Merriam's kangaroo rats. Journal of Mammalogy 70: 27-34.

Jones W. T., Waser P. M., Elliott L. F., Link N. E. and Bush B. B. 1988. Philopatry, dispersal and habitat saturation in the banner-tailed kangaroo rat. Ecology 69: 1466-1473.

Karaseva E. V. and Ilyenko A. J. 1957. [Some biological properties of root vole estimated by capture-recapture method]. Fauna i Ekologija Gryzunov 5: 12-19. [In Russian]

King C. M. 1985. Interactions between woodland rodents and their predators. Symposia of the Zoological Society of London 55: 219-247.

Korn H. 1986. Changes in home range size during growth and maturation of the wood mouse (Apodemus sylvaticus) and the bank vole (Clethrionomys glareolus). Oecologia (Berlin) 68: 623-628.

Kozakiewicz M. and Jurasińska E. 1989. The role of habitat bariers in woodlot recolonization by small mammals. Holarctic Ecology 12: 106-111.

Kozakiewicz M. and Szacki J. 1995. Movements of small mammals in a landscape: patch restriction or nomadism? [In: Landscape approaches in mammalian ecology and conservation. W. Z. Lidicker Jr, ed]. Lniversity of Minnesota Press, Minneapolis: 78-94.

Körpimaki E., Norrdhal K. and Valkama J. 1994. Reproductive investment under fluctuacting predation risk: microtine rodents and small mustelids. Evolutionary Ecology 8: 357-368.

Krebs J. R. 1980. Optimal foraging, predation risk and territory defense. Ardea 68: 83-90.

Krebs J. R. 1996. Population cycles revisited. Journal of Mammalogy 77: 8-24.

Lavrova M. J. and Andreeva D. A. 1960. Voles as main and secondary carriers of leptospirae (based on the data of observations on tagged animals). Zoologicheskiï Zhurnal 39: 608-616. [In Russian with English summary] 
Liro A. and Szacki J. 1995. Movements of small mammals along two ecological corridors in suburban Warsaw. Polish Ecological Studies 20: 227-231.

Löfgren O. 1995. Spatial organization of cyclic Clethrionomys females: occupancy of all available space at peak densities? Oikos 72: 29-35.

Löfgren O., Hörnfeldt B. and Eklund U. 1996. Effect of suplemental food on a cyclic Clethrionomys glareolus population at peak density. Acta Theriologica 41: 383-394.

Lukyanov O. 1995. Analysis of dispersal in small mammal populations. Polish Ecological Studies 20: 237-242.

Mazurkiewicz M. 1971. Shape, size and distribution of home range of Clethrionomys glareolus (Schreber, 1780). Acta Theriologica 16: 23-60.

Mazurkiewicz M. 1981. Spatial organization of a bank vole popuation in years of small or large density. Acta Theriologica 26: 31-45.

Mazurkiewicz M. 1984. Population density of small rodents as affected by chosen elements of tree stand structure. Bulletin de L'Academie Polonaise de Science, serie de sciences biologiques 32: 209-217.

Mazurkiewicz M. 1986. The influence of undergrowth distribution on utilization of space by bank vole populations. Acta Theriologica 31: 55-69.

Mazurkiewicz M. 1991. Population dynamics and demography of the bank vole in different tree stands. Acta Theriologica 36: 207-227.

Mazurkiewicz M. 1994. Factors influencing the distribution of the bank voles in the forest habitats. Acta Theriologica 39: 113-126.

Mazurkiewicz M. and Rajska-Jurgiel E. 1975. Dispersion of bank voles from their place of birth. Acta Theriologica 20: 71-81.

Mazurkiewicz M. and Rajska-Jurgiel E. 1978. Size and structure of rodent community of various forest stand type. Bulletin de L'Academie Polonaise de Science, serie de sciences biologiques 26: 669-677.

Mazurkiewicz M. and Rajska-Jurgiel E. 1987. Numbers, species composition and residency of a rodent community in forest and field-forest ecotones. Acta Theriologica 32: 413-432.

Merriam G. and Lanoue A. 1990. Corridor use by small mammals: field measurements for three experimental types of Peromyscus leucopus. Landscape Ecology 4: 123-131.

Montgomery W. J, 1979. Seasonal variation in numbers of A. sylvaticus, A. flavicollis, C. glareolus. Journal of Zoology, London 188: 283-286.

Montgomery W. J. 1980. Population structure and dynamics of sympatric Apodemus species. Journal of Zoology, London 192: 351-377.

Montgomery W. J, and Gurnell J. 1985. The behaviour of Apodemus. Symposia of the Zoological Society of London 55: 89-108.

Nikitina N. A. 1970. On permanency in the use of territories by rodents. Fauna i Ekologija Gryzunov 9: 110-134. [In Russian with English summary]

Nikitina N. A. and Merkova M. A. 1963. [Space use in nice and voles estimated by capture-recapture method]. Byulletin Moskovskogo Obshchestva Ispytateleï Prirody 68: 15-21. [In Russian]

Ostfeld R. S. 1985. Limiting resources and territoriality in microtine rodents. American Naturalist 126: $1-15$.

Petrusewicz K. 1983. Numbers: the concept and definitions. [In: Ecology of the bank vole. K. Petrusewicz, ed]. Acta Theriologica 28, Supplement 1: 89-101.

Pimm S. I. and Rozenzweig M. L. 1981. Competitors and habitat use. Oikos 37: 1-6.

Plesner-Jensen S. 1996. Juvenile dispersal in relation to adult densities in wood mice Apodemus syluaticus. Acta Theriologica 41: 177-186.

Pucek M. 1983. Habitat preference. [In: Ecology of the bank vole. K. Petrusewicz, ed]. Acta Theriologica 28, Supplement 1: 31-40.

Pucek Z., Jędrzejewski W., Jędrzejewska B. and Pucek M. 1993. Rodent population dynamics in a primeval deciduous forest (Białowieża National Park) in relation to weather, seed crop, and predation. Acta Theriologica 38: 199-232. 
Rajska-Jurgiel E. 1992. Demography of woodland rodents in fragmented habitat. Acta Theriologica 37: 73-90.

Rajska-Jurgiel E. and Mazurkiewicz M. 1988. The effect of spatial structure of environment on density of rodents in suburban zone. Polish Ecological Studies 14: 145-169.

Salsbury C. M. and Armitage K. B. 1994. Home range size and exploatory excursions of adult male yellow-bellied marmots. Journal of Mammalogy 75: 648-655.

Shoener 1971. Theory of feeding, Annual Reviews of Ecology and Systematics 2: 369-404.

Smith M. H. 1971. Food as a limiting factor in the population ecology of Peromyscus polionotus (Wagner). Annales Zoologici Fennici 8: 109-112.

Smyth M. 1966. Winter breeding in woodland mice, Apodemus silvaticus and voles, Clethrionomys glareoius and Microtus agrestis, near Oxford. Journal of Animal Ecology 35: 471-485.

Stenseth N. C. and Lidicker Z. L., Jr (eds) 1992. Animal dispersal: small mammals as a model. Chapnan and Hall, London: 1-365.

Szacki J. and Liro A. 1991. Movements of small mammals in the heterogeneous landscape. Landscape Ecology 5: 219-224.

Taitt M. J and Krebs C. J. 1985. Population dynamics and cycles. [In: Biology of New World Microtus. R. Tanarin, ed]. Special Publications of American Society of Mammalogists 8: 567-620.

Wegner J and Merriam G. 1990. Use of spatial elements in a farmland mosaic by a woodland rodent. Biologcal Conservation 54: 263-276.

Wiger R. 1982. Roles of self regulatory mechanisms in cyclic populations of Clethrionomys with special refereice to C. glareolus, a hypothesis. Oikos 38: 60-71.

Wiens J. A., Stenseth N. C., Van Horne B. and Ims R. A. 1993. Ecological mechanism and landscape ecologr. Oikos 66: 369-380.

Wolff J. C. 1985. The effects of density, food and interspecific interference on home range size in P. leuopus and P. maniculatus. Canadian Journal of Zoology 63: 2657-2662.

Wolff J. O 1993. Why are female small mammal territorial? Oikos 68: 364-370.

Wolff J. C. 1996. Population fluctuations of mast-eating rodents are correlated with production of acorns Journal of Mammalogy 77: 850-856.

Wolff J. C, and Cicirello D. M. 1989. Field evidence for sexual selection and resource competition infantcide in white-footed mice. Animal Behaviour 38: 637-642.

Wolff J. O and Cicirello D. M. 1990. Mobility versus territoriality: alternative reproductive strategies in whie-footed mice. Animal Behaviour 39: 1222-1224.

Wolff J. O, Lundy K. J. and Baccus R. 1988. Dispersal inbreeding avidance and reproductive success in whie-footed mice. Animal Behaviour 36: 456-465.

Ylönen H, Jędrzejewska B., Jędrzejewski W. and Heikkila J. 1992. Antipredatory behavior of Clethronomys voles - 'David and Goliath' arms race. Annales Zoologici Fennici 29: 207-216.

Ylönen H. Kojola T. and Viitala J, 1988. Changing female spacing behaviour and demography in an enclostd breeding population of Clethrionomys glareolus. Holarctic Ecology 11: 286-292.

Ylönen H. Pusenius J. and Viitala J. 1995. Impact of kinship and familiarity on the annual social organiation and population dynamics of Clethrionomys and Microtus voles. Annales Zoologici Fennic 32: 225-232.

Zejda J. 962. Winter breeding in the bank vole, Clethrionomys glareolus. Zoologické Listy 10: $249-214$.

Zejda J. and Pelikan J. 1969. Movements and home ranges of some rodents in lowland forest. Zoologeké listy 18: 143-162.

Zemanek A. 1972. Food and feeding habits of rodents in a deciduous forest. Acta Theriologica 17: $315-3: 5$.

Received R January 1997, accepted 2 October 1997. 